Folia Historica Cracoviensia, 22: 2016, s. 603-624

DOI: http://dx.doi.org/10.15633/fhc.2098

Zdzisław Gogola ofmconv

Uniwersytet Papieski Jana Pawea il w Krakowie

\title{
Misje i męczeństwo \\ polskich franciszkanów w Peru
}

Kontynent Ameryki Południowej, w tym Peru, ewangelizowany jest od ponad 500 lat. Przemierzyło go tysiące misjonarzy, wśród nich również Polacy. Wielu misjonarzy oddało swe życie za wiarę. Pierwsze udokumentowane ślady działalności franciszkanów na ziemi peruwiańskiej sięgają pierwszej połowy XVI wieku. Po blisko stuletnim pobycie zostali wchłonięci przez nową reformowaną gałąź - obserwantów. Franciszkanie, którzy nie przyjęli reformy, musieli wyjechać do Europy. Do Peru franciszkanie wrócili po ponad 400 latach, w roku 1988, w związku z utworzoną przez krakowską prowincję franciszkanów św. Antoniego i bł. Jakuba Strzemię misją peruwiańską. Tematem niniejszego artykułu jest ponad dwudziestoletnia działalność misyjna Braci Mniejszych Konwentualnych w Peru ${ }^{1}$.

\section{Franciszkańska reewangelizacja Peru}

Pierwsze rozmowy na temat zorganizowania misji w Peru rozpoczęto w 1983 roku. Dwa lata później (1985) Kuria Generalna Zakonu Braci Mniejszych Konwentualnych w Rzymie opracowała projekt założenia nowej placówki misyjnej, który przedstawiono do realizacji Prowincji św. Antoniego w Stanach Zjednoczonych. Obiektywne trudności uniemożliwiły amerykańskiej prowincji podjęcie tego

\footnotetext{
1 Tematyka misji peruwiańskiej została szeroko opisana w publikacjach: Z. Gogola, W peruwiańskie Andy z Pokojem i Dobrem, Kraków 2001; Z. Gogola, Działalność misyjna Braci Mniejszych Konwentualnych w Peru, Kraków 2003; Z. Gogola, La vida que nace del martirio. Los misioneros franciscanos conventuales en Perú, Palencia 2006; Z. Gogola, Męczennicy z Pariacoto, Kraków 2016.
} 
zadania. Wobec zaistniałej sytuacji zarząd generalny zakonu zwrócił się do polskiej Prowincji św. Antoniego i bł. Jakuba Strzemię, która już wcześniej zaangażowała się w pracę ewangelizacyjną na terenie Ameryki Południowej, prowadząc od roku 1976 misję w Boliwii ${ }^{2}$. Rada Prowincjalna, po rozpatrzeniu propozycji, wydelegowała do Peru misjonarza w Boliwii o. Peregryna Ziobrę celem pełniejszego rozeznania sytuacji w tym kraju. Po rekonesansie o. Ziobro przedstawił prowincjałowi o. Feliksowi Stasicy sprawozdanie, w którym omówił zasadność pracy krakowskich franciszkanów w Peru ${ }^{3}$. W oparciu o tę, jak i inne przesłanki - 30 czerwca 1988 roku Rada Prowincji podjęła decyzję o przyjęciu propozycji Kurii Generalnej i utworzeniu misji na terenie peruwiańskiej diecezji Chimbote ${ }^{4}$.

Na podjęcie tego zadania w Peru zdecydowali się o. Zbigniew Strzałkowski i o. Jarosław Wysoczański. Po odpowiednich przygotowaniach i pokonaniu przeszkód, które stwarzały władze PRL-u przy staraniach o wizy, misjonarze w końcu dotarli na ziemię peruwiańską. Było to 30 listopada 1988 roku. Rozpoczęli od intensywnej nauki języka hiszpańskiego, poznawania miejscowej kultury, zwyczajów i religijności. Przez pierwsze osiem miesięcy pracowali w wyznaczonych przez władze kościelne parafiach: o. Jarosław Wysoczański w Chimbote, a o. Zbigniew Strzałkowski w Moro. W lipcu 1989 roku przybył do Peru kolejny misjonarz - o. Michał Tomaszek. Z początkiem sierpnia tego roku wszyscy trzej osiedlili się w Pariacoto, dając początek nowej misji i tworząc wspólnotę zakonną (il. 1, 2) $)^{5}$.

Misjonarzy zaskoczył rytm tamtejszego życia, odmierzany naturalnym zegarem: wschodami i zachodami słońca, oraz ogromna cisza panująca w Andach. Franciszkanie z Polski zatrzymali się w ośrodku misyjnym wybudowanym po trzęsieniu ziemi w 1970 roku $^{6}$ przez siostry zgromadzenia Esclavas del Sagrado

Zob. J. Bajowski, Boliwia - franciszkanie, historia i duch misji, Kraków 1999.

3 Zob. Archiwum Kurii Prowincjalnej Ojców Franciszkanów w Krakowie [dalej: AKPK], Korespondencja o. Peregryna Ziobroz 14.04.1988.

4 Zob. „Wiadomości z Prowincji św. Antoniego i bł. Jakuba Strzemię oo. Franciszkanów w Polsce” [dalej: „Wiadomości z Prowincji”] (1987) nr 3, s. 4.

5 Zob. Archiwum Franciszkanów w Pariacoto [dalej: AfP], Crónica de la vida conventual y del trabajo pastoral de los Adres Franciscanos Conventuales de Pariacoto 1989-1991 [dalej: Crónica de Pariacoto], s. 3-4.

6 Skutki trzęsienia ziemi w 1970 roku okazały się dla Pariacoto tragiczne. Śmiercionośna lawa błotna zniszczyła połowę osady wraz ze starym kościołem w części Pueblo Viejo. Siostry Esclavas, które przybyły do Pariacoto $\mathrm{w}$ kwietniu 1971 roku, zajęły się pomocą dla ludności: prowadziły lekcje dla dzieci i dorosłych, zajmowały się sprawami administracyjnymi i duszpastersko-katechetycznymi. Zainicjowały budowę centrum katechetycznego i kościoła. Relacja s. Any Marii Chavez Hulman, Pariacoto, 30.07.2001. 
Corazón. Znajdował się on przy centralnym placu osady. Wiadomość o przybyciu franciszkanów do wioski rozeszła się szybko. Misja obejmowała ponad 6o górskich osad na rozległym obszarze (około tysiąca kilometrów kwadratowych). Do większości wiosek dojazd był bardzo trudny i zajmował kilka godzin jazdy samochodem. W wielu wypadkach nie można było dojechać do samego celu podróży i resztę dystansu trzeba było pokonać konno lub pieszo 7 .

Sprawę misji usankcjonowano formalnie 2 lutego 1990 roku. W Chimbote została podpisana umowa przez bpa Luisa Bambaréna reprezentującego diecezję i prowincjała o. Zdzisława Gogolę, przedstawiciela prowincji krakowskiej. Zgodnie z jej postanowieniami diecezja Chimbote przekazała zakonowi na własność misję w Pariacoto, pozwalając jednocześnie na założenie klasztoru (il. 3, 4). Klasztor erygowano 15 marca 1990 roku $^{8}$. Przełożonym misji został poprzez mianowanie o. Jarosław Wysoczański ${ }^{9}$.

Drugą placówką misyjną franciszkanów z prowincji krakowskiej była Lima. Oddalony od Pariacoto ponad 500 kilometrów klasztor w Limie miał stanowić centrum misyjne, miejsce do zatrzymania się, w którym można było znaleźć oparcie, pomoc i poradę. Tutaj organizowano kursy formacyjne. W centrum miało powstać studium nauczania - dom formacyjny dla młodych Peruwiańczyków. Planowano także utworzyć centrum medyczne i zorganizować urząd misyjny oraz archiwum dla usprawnienia kontaktów z prowincją w Polsce i z Kurią Generalną w Rzymie. Odpowiednią lokalizację znaleziono w dzielnicy Salamanca, zamieszkanej przez ludność średnio zamożną. W tej części Limy pracowali już franciszkanie Trzeciego Zakonu Regularnego (тоR) z Włoch i Hiszpanii. Prowadzili tu ponad stutysięczną parafię. Arcybiskup Limy kard. Landazuri Richetts wyodrębnił z dotąd istniejącej parafii nową jednostkę duszpasterską i przekazał ją wraz z kościołem w budowie polskim franciszkanom na 10 lat ${ }^{10}$. Proboszczem nowo powstałej parafii został o. Szymon Chapiński, doświadczony misjonarz z Boliwii. Zamieszkał tymczasowo w klasztorze braci z ToR-u. Po ukończeniu budowy mieszkalnej części klasztoru franciszkańskiego przeniósł się do domu zakonnego, gdzie zamieszkał wraz z br. Grzegorzem Brożyną przybyłym do Limy z boliwijskiej Kustodii św. Franciszka ${ }^{11}$. Razem kontynuowali pracę przy dalszej

7 Zob. AfP, Crónica de Pariacoto, s. 4.

8 Zob. Акрк, Teka Pariacoto. Projekt umowy z 2.02.199o.

9 Zob. AKPK, Teka Pariacoto. Dokument nominacyjny o. Jarosława Wysoczańskiego na przełożonego domu zakonnego $w$ Pariacoto $z$ 30.12.1989.

10 Zob. Акрк, Teka Lima. Korespondencja abpa Limy do prowincjała w Krakowie z 27.04.1989.

${ }_{11}$ Zob. Archiwum Parafii w Limie [dalej: APL], Crónica Franciscanos Conventuales. Lima 1990-1991 [dalej: Crónica Lima], s. 3-5. 
budowie świątyni, inwestycja przejęta była w początkowym stadium budowy. W części piwnicznej wysokość wzniesionych murów wynosiła zaledwie dwa metry. Ojciec Chapiński poza obowiązkami związanymi z budową posługiwał jednocześnie w nowej parafii oraz w kaplicy św. Matyldy w dzielnicy San Luis ${ }^{12}$.

Zaangażowanie $\mathrm{w}$ prace budowlane przy klasztorze było większe, dlatego 24 września 1990 roku dokonano „otwarcia” domu zakonnego. Konwent nie był jednak dostatecznie urządzony, wyposażano go systematycznie w niezbędne urządzenia i meble, tak by mógł normalnie funkcjonować. Fundusze inwestycyjne zabezpieczała w dużej części Kuria Generalna zakonu; także mieszkańcy parafii wspierali budowę swoimi ofiarami i pracą. Starano się również o dofinansowanie od Adveniat z Niemiec - instytucji wspomagającej misje. Praca duszpasterska w Limie nie należała do bezpiecznych zajęć. Z powodu zamachów terrorystycznych zagrożone było życie zarówno misjonarzy, jak i wiernych. Szczególnie niebezpieczny okazał się październik 1990 roku, kiedy to znacznie zintensyfikowały się działania terrorystyczne ${ }^{13}$. Praktycznie nie funkcjonowała poczta ani banki. Występowały uciążliwe przerwy w dostawach energii elektrycznej i wody. Wybuchy bomb i coraz częstsze ataki terrorystów Sendero Luminoso stanowiły codzienny obraz rzeczywistości. Życie w Limie stawało się coraz trudniejsze. Mieszkańcy byli zmęczeni istniejącą sytuacją, zastraszeni i niepewni jutra. Poruszanie się po dzielnicy, w której pracowali franciszkanie, było bardzo ryzykowne, szczególnie wieczorem ${ }^{14}$. W maju 1991 roku terroryści ukradli klasztorny samochód i użyli go jako bomby-pułapki ${ }^{15}$.

Trzecim miejscem misji franciszkańskiej było miasto Chimbote, siedziba ordynariusza diecezji. Franciszkanie przejęli tutaj parafię św. Franciszka z Asyżu. Celem tego posunięcia było wsparcie misji w Pariacoto. Niestety, decyzję o przejęciu parafii w Chimbote odłożono do roku 1994, a to $z$ uwagi na tragiczne wydarzenie w Pariacoto w roku 1991 - męczeńską śmierć franciszkańskich misjonarzy Zbigniewa Strzałkowskiego (il. 5) i Michała Tomaszka (il. 6) ${ }^{16}$. Na początku roku 1995 pracę w Chimbote rozpoczął o. Marek Wilk, później dołączył

12 Zob. APL, Crónica Lima, s. 10.

13 Zob. APL, Crónica Lima, s. 59.

14 Zob. Акрк, Teka Lima. Korespondencja o. Szymona Chapińskiego do prowincjała $z$ 12.03. i $z$ 27.06.1990.

15 W samochodzie umieszczono 100 kg materiałów wybuchowych. Zob. APL, Crónica Lima, s. 99-100.

${ }^{16}$ Zob. Z. Gogola, Działalność misyjna Braci Mniejszych Konwentualnych w Peru, Kraków 2003, s. 433, 441, 442-458; Z. Gogola, W peruwiańskie Andy z pokojem i dobrem, Kraków 2001, s. $176,177-206$. 
do niego o. Stanisław Niedziela ${ }^{17}$. Franciszkańska placówka duszpasterska była jedną z największych spośród 18 parafii w Chimbote. Podzielono ją na osiem rejonów i wyróżniono dwie części: miejską i wiejską. Najdalszy rejon parafii oddalony był od jej centrum o trzy godziny jazdy samochodem. W Chimbote franciszkanie posługiwali też jako kapelani w miejscowym więzieniu. Społeczność parafii przyjęła franciszkanów z entuzjazmem. Oczekiwania miejscowej ludności były bardzo zróżnicowane. Wielu parafian łączyło przyjazd misjonarzy z myślą o poprawie warunków życia, wierząc, że obcokrajowcy przywieźli duże pieniądze. Sytuacja była jednak skomplikowana. Na terenie parafii działało wiele sekt, do których przyłączali się parafianie w nadziei na korzyści materialne. Oficjalna przynależność religijna dla części ludności tubylczej była sprawą drugorzędną, a często w ogóle mało istotną ${ }^{18}$.

\section{Metody i formy działalności}

Praca misjonarzy we wszystkich trzech placówkach przebiegała na dwóch płaszczyznach. Pierwszą stanowiła aktywność duszpasterska, a więc posługa sakramentalna oraz głoszenie słowa Bożego. Drugą była działalność społeczno-charytatywna. Praca duszpasterska wsparta była na strukturach parafii, które włączone były w organizm diecezji. Zgodnie z zaleceniem biskupów proboszczowie byli zobowiązani do powoływania w swoich parafiach rad duszpasterskich i ekonomicznych, których celem była pomoc duchownym w prowadzeniu i administrowaniu daną placówką. Jeden z misjonarzy był wyznaczany na stanowisko proboszcza, pozostali natomiast pomagali mu we wszystkich obowiązkach. Jak zaznaczono, parafie były rozległe i wymagały większej liczby kapłanów oraz odpowiednich środków technicznych. Jednych i drugich zwykle brakowało.

Misjonarze $\mathrm{z}$ Pariacoto odwiedzali swoich parafian w oddalonych i rozrzuconych na dużym obszarze wioskach i punktach misyjnych. Tam głosili proste kazania, udzielali sakramentów, nieśli słowa pociechy. Taka metoda działania była pracochłonna, ale skuteczna. Żeby szybciej i szerzej docierać do wiernych, czyniono próby założenia misyjnej radiostacji, która byłaby w tej sytuacji bardzo przydatna zarówno w głoszeniu Ewangelii, jak i w przekazywaniu wiadomości

17 Zob. „Wiadomości z Prowincji” (1995) nr 198, z. 3, s. 45.

18 Zob. АКРК, Korespondencja o. Jarosława Wysoczańskiego do prowincjałów $z 1995$ r. 
na terenie parafii. Całość pracy duszpasterskiej w misji ujęto w trzech sektorach działań: katechetycznym, socjalnym i medycznym.

Pierwszym zadaniem i wyzwaniem dla misjonarzy była niewątpliwie katechizacja. W Pariacoto utworzono specjalny ośrodek kształcenia katechetów, do którego w określonym terminie przybywali ochotnicy z różnych miejscowości, na kilkudniowe szkolenia. Kursy były trzystopniowe. Dla tzw. campesinos najczęściej zaczynały się od nauki czytania i pisania. Później przystępowano do realizacji programu kształcenia katechetycznego. Katecheci w swoich osadach nie tylko uczyli religii, ale też aktywizowali miejscową ludność na rzecz lokalnej wspólnoty chrześcijańskiej: budowania kaplic, organizowania uroczystości i spotkań katechetycznych ${ }^{19}$. Można powiedzieć, że zastępowali w pewnej mierze misjonarza. Była to jedna $\mathrm{z}$ lepszych i sprawdzonych metod dotarcia $\mathrm{z}$ Ewangelią do ludności, która praktycznie nigdy nie opuszczała swoich siedzib w górach. Tubylcy najlepiej przyswajali sobie te prawdy, które można było zilustrować przykładem, obrazem, przypowieścią. Campesinos byli najczęściej analfabetami, stąd katecheci nie „wykładali”, lecz opowiadali im Ewangelię. Była ona dla nich dość zrozumiała i jasna, gdyż opisywane dawne, starożytne społeczności, ich zwyczaje i zachowania, miały wiele cech wspólnych z prostym, ubogim życiem mieszkańców tej części Andów ${ }^{20}$.

Ważnym elementem pracy ewangelicznej była umiejętnie wprowadzana przez misjonarzy inkulturacja. Zakładała ona szacunek dla dorobku kulturowego i tradycji Peru oraz możliwość zadomowienia się chrześcijaństwa w tamtym systemie wartości, bez szkody dla niego samego, jak i dla rodzimej kultury. Uwzględniała uwarunkowania naturalnych grup i wiosek, gdzie więzi kulturowe i religijne są podobne. Dla ludzi gór Kościół w swoich zewnętrznych strukturach jest mało zrozumiałą instytucją, natomiast jako mała, miejscowa wspólnota jest akceptowalny i przyswajalny. $Z$ tego także względu ludność chętnie gromadziła się podczas uroczystości poświęconych patronom parafii, czyli na odpustach, zwanych tam fiestas, które adaptowały dawne obrzędy i zwyczaje tubylców. Zgromadzenia takie $\mathrm{z}$ udziałem orkiestry i tradycyjnych tancerzy, połączone z procesją, ale i z dobrym posiłkiem, zyskały nowy chrześcijański wymiar. Fiesta była bardzo kosztowna, przeznaczano na nią wszystkie zaoszczędzone pieniądze w nadziei, że patron godnie odwdzięczy się wiosce za okazaną mu pamięć, że zatroszczy się

19 Rolę i znaczenie katechetów oraz świeckich misjonarzy w dziele ewangelizacji mocno zaakcentował Sobór Watykański II, mówiąc o ludziach wybranych do pracy na niwie Pańskiej: Ad Gentes, Dekret o działalności misyjnej Kościoła, II, nr 17; IV, nr 23, 26, 30, 41.

${ }_{20}$ Zob. AfP, Crónica de Pariacoto, s. 11. 
o dobre plony oraz o pomyślność swoich „podopiecznych”"1. Europejski kalendarz kościelny musiał być zmieniony w Peru. Poszczególne okresy liturgiczne nie pokrywały się z „duchem” roku mieszkańców w Andach. Toteż w czasie, kiedy w Europie przypadał Wielki Post czy Adwent, w wioskach andyjskich odbywały się zabawy, udzielano ślubów i organizowano wesela. Inaczej rozumiano przygotowanie do świąt, inaczej rozumiano smutek i radośćc ${ }^{2}$.

Misjonarze byli zazwyczaj jedynymi przybyszami, którzy docierali do wiosek położonych nawet na wysokości 4500 metrów n.p.m. Najpierw trzeba było pokonać nieufność mieszkańców, ale i wtedy owoce często okazywały się nader mizerne. Bywało, że niektórzy misjonarze doświadczali zwątpienia w sens swoich wysiłków ${ }^{23}$. Wybór metody pracy na misji w Peru nie był prosty. W pracy duszpasterskiej misjonarze musieli być bardzo czujni, by nie oskarżono ich o działalność polityczną, musieli umieć się znaleźć w każdej sytuacji. W Limie i Chimbote stosowano sprawdzoną metodę duszpasterską. Była nią praca w parafii. Praca ta niewiele różniła się od działalności duszpasterskiej w Polsce, uwzględniała jedynie lokalne tradycje ludowe. Działalność misyjna polegała też na pomocy socjalnej i pracach społeczno-charytatywnych. Ma to swoje uzasadnienie w encyklice Rerum novarum Leona XIII, który pisał, że „tradycyjna jałmużna nie wystarcza wobec nędzy niezasłużonej, która dotknęła szczególnie klasę robotniczą" ${ }^{24}$. Chociaż nie jest rolą Kościoła bezpośrednia troska o sprawy materialne wierzących, to nie jest on obojętny na biedę i wszystko, co tylko jest możliwe w tej kwestii, czynił i czyni, aby ulżyć losowi ubogich. Misjonarz pracujący w Ameryce Południowej często staje wobec dylematu: głosić Ewangelię czy nakarmić tłumy ${ }^{25}$ ? W ramach prowadzonych dzieł misyjnych mieści się także „posługa socjalna”, czyli troska o zaspokojenie podstawowych potrzeb życiowych człowieka $^{26}$. Franciszkanie niejeden raz „nakarmili” owe tłumy, rozprowadzając pośród swoich parafian artykuły żywnościowe przesłane przez Caritas. Podejmowali również szereg inicjatyw, by ulżyć doli campesinos poprzez rozwiązywanie codziennych problemów związanych choćby z brakiem wody w Pariacoto, brakiem medycznego transportu - przez dowożenie chorych do szpitali, czy przez finansowe wspieranie ubogich rodzin w urządzaniu godnych pochówków.

${ }^{21}$ Zob. AFp, Crónica de Pariacoto, s. 11.

${ }_{22}$ Zob. Relacja o. Stanisława Olbrychta, Pariacoto, 14.07.2009.

${ }_{23}$ Zob. Relacja o. Michała Tomaszka, Pariacoto, 3.02.199o.

${ }^{24}$ Leon XIII, Rerum novarum, 15.05.1891.

25 Zob. J. Górski, Propedeutyka misjologii, Kraków 200o, s. 62-63.

26 Zob. K. Müller, Posłannictwo misjonarza dzisiaj, „Collectanea Theologica” (1975) nr 45, S. 147 . 
Angażowali się w projekty budowy dróg, szkół, zbiorników na wodę. Przyczynili się w znacznym stopniu do powstania liceum w Pariacoto. Kuria Generalna w Rzymie przyznała na budowę szkoły kwotę 10 tysięcy dolarów. Ojciec Stanisław Olbrycht wraz z o. Michaelem Stockingerem pracowali nad projektowaniem odpowiednich dachówek, mostów, parków dla dzieci.

Franciszkanie uczyli miejscowych także „marketingu”, czyli umiejętności sprzedaży produktów na wybrzeżu Pacyfiku. Organizowali w Pariacoto kursy inżynieryjno-prawne, na których miejscowi chłopi dowiadywali się, jak nie dać się oszukać pośrednikom i sprzedać z korzyścią swoje rękodzieła. Kolejnym sektorem aktywności misyjnej była działalność związana $\mathrm{z}$ ochroną zdrowia. Franciszkanie współpracowali w tym względzie ze służbami medycznymi w zwalczaniu epidemii cholery, organizowali "sanatoryjno-wypoczynkowe” wyjazdy dla dzieci i młodzieży. Partycypowali w budowie punktów sanitarnych. W Limie zorganizowano zbiórkę lekarstw i żywności, które dostarczono do Iquitos ${ }^{27}$. W stolicy Peru franciszkanie otwarli centrum medyczne, które służy ludności zamieszkałej na terenie parafii Matki Bożej Miłosierdzia, szczególnie najuboższym. Systematycznie poszerzany jest zakres usług leczniczych. Opłaty za usługi medyczne są symboliczne - około 30 proc. pacjentów nie ponosi żadnych opłat. W ramach opieki centrum medyczne organizuje w każdą niedzielę dwudaniowe obiady dla 50 dzieci ${ }^{28}$.

\section{Trudne realia}

Jak już wspomniano, zaraz po przyjeździe do Pariacoto młodych misjonarzy zaskoczyły pewne oczekiwania tubylczej ludności, która spodziewała się po „białych" pomocy materialnej. Tymczasem sami misjonarze borykali się z trudnościami finansowymi. Nie posiadali nawet kuchennych naczyń, by przygotowywać sobie posiłki, ani żadnych narzędzi potrzebnych do remontów i napraw budynku katechetycznego adaptowanego na dom zakonny. W tym czasie franciszkanie korzystali z gościnności sióstr Esclavas del Sagrado Corazón, które zapraszały ich do swego klasztoru na posiłki ${ }^{29}$.

\footnotetext{
27 Zob. AFL, La crónica convento 1996-20oo, s. 39, 113.

28 Zob. Z. Gogola, Działalność misyjna..., dz. cyt., s. 510-511, 514.

29 Zob. AKPK, Korespondencja ojców Zbigniewa, Michała i Jarosława do prowincjała $z 30.10 .1989$.
} 
Praca duszpasterska wymagała od franciszkanów bardzo dużego wysiłku. „Porozrzucane" w strefie wysokich gór na obszarze tysiąca kilometrów kwadratowych wioski, brak dróg, kaplic, miejsc noclegowych, a także trudności w porozumiewaniu się z mieszkańcami, którzy nie zawsze znali język hiszpański, lecz jedynie język keczua - sprawiały, że misjonarz czuł się bezradny. Także sprawowanie sakramentów świętych było dla wielu peruwiańskich chrześcijan czymś niezrozumiałym i dawno zapomnianym - katechiści tłumaczyli ab ovo poszczególne znaki i treść tekstów obrzędowych ${ }^{30}$. Potrzeba było wiele cierpliwości i pokory, aby dotrzeć do duszy andyjskiego człowieka, który jest raczej zamknięty wewnętrznie i unika bliższych kontaktów z misjonarzem. Duszpasterz z Polski trafiał więc w środowisko, którego nie znał i nie rozumiał wystarczająco. Dotyczyło to również problemu istnienia i wpływów ruchu terrorystycznego spod znaku Sendero Luminoso, którego często nie był świadomy ${ }^{31}$. Misjonarze znaleźli się na tych terenach w czasie, kiedy Abimael Guzmán pod pseudonimem Presidente Gonzalo podjął walkę zbrojną. Było to dostosowanie komunistycznej rewolucji do sytuacji peruwiańskiej. Górzyste departamenty Peru, trudno dostępne, słabo chronione przez władze państwowe, były polem wielu nadużyć. Prawdziwą plagą byli złodzieje bydła. Gonzalo opracował taktykę pozwalającą zdobyć przychylność ludności. W latach 70. Świetlisty Szlak zaczął intensywnie zwalczać złodziei bydła. Zabijanie ich terroryści przedstawiali jako przejaw „ludowej sprawiedliwości”. Ruch zdobywał sobie coraz więcej sympatyków, którzy akceptowali nawet zabijanie policjantów i wójtów wiosek za ich „opieszałość i słabe dbanie o interesy ludu”. Gdy rewolucja objęła jedną trzecią powierzchni Peru, Gonzalo, mając 10 tys. bojowników, poczuł się silny i porzuciwszy wcześniejszą taktykę, w maju 1980 roku ogłosił, że nadszedł czas na obalenie władzy i wszczęcie rewolucji.

Świadomość religijna mieszkańców gór była niska, choć miejscowe społeczności wykształciły dość okazały w formach kult Matki Bożej i świętych. Peruwiańczycy chętnie uczestniczyli w liturgii i nabożeństwach; równie chętnie brali udział w organizowanych fiestas i procesjach z okazji świąt kościelnych. Niestety, wielu uczestników tych religijnych uroczystości znajdowało się pod wpływem

30 Zob. AfP, Crónica de Pariacoto, s. 108-112, 114.

${ }^{31}$ Sendero Luminoso (Świetlisty Szlak) - maoistowska organizacja terrorystyczna w Peru, nazywająca siebie Komunistyczną Partią Peru, eliminowała fizycznie przedstawicieli klas panujących, właścicieli zakładów, sił porządkowych, a także cudzoziemców; otwarcie występowała przeciw Kościołowi. Na czele senderystów stał Abimael Guzmán. Stosował on maoistowską metodę walki, tj. ciągłej wojny w celu przejęcia władzy. Centrum ruchu znajdowało się w regionie Ayacucho. C. J. Degregori, Sendero Luminoso, Lima 1988, s. 24-26; S. Goldemberg, Sendero la Universidad, „Caretas" (1981) nr 671, s. 10-15. 
alkoholu. Nadto znajomość prawd wiary i katechizmu pozostawiała wiele do życzenia. Mieszkańcy gór nie potrafili wymienić dziesięciu przykazań Bożych, nie znali podstawowych modlitw: Ojcze nasz i Zdrowaś Maryjo ${ }^{32}$.

Wspólne świętowanie dawało im poczucie siły, przekonanie o więzi wszystkich współplemieńców. W niektórych wioskach kultowi świętych towarzyszyła wiara w dawne inkaskie bóstwa, u których również szukano pomocy w trudnych sytuacjach życiowych, zwłaszcza gdy zawiodły modlitwy kierowane do świętych chrześcijańskich. W tym ostatnim wypadku stosowano nawet praktykę „karania świętych" za opieszałość. Gdy w czasie przedłużającej się suszy procesyjnie obchodzono pola $\mathrm{z}$ figurą świętego patrona wioski i praktyki te nie przynosiły pożądanego skutku, wówczas "rozbierano" świętego, to jest pozbawiono figurę szat, i zostawiano $\mathrm{w}$ polu, aby prażył się w słońcu. Z innych metod karania świętych stosowano praktykę odwracania figury twarzą do ściany, zaklejanie świętemu oczu czarnym plastrem; św. Józefa karano poprzez odebranie mu trzymanego na rękach Dzieciątka Jezus. Na to miejsce w równie uroczystej procesji przyprowadzano indiańskiego bożka Ilyapa, wierząc w jego moc sprowadzania deszczu ${ }^{33}$.

Wśród miejscowych społeczności wielką czcią otaczano zmarłych, uważano, że nadal uczestniczą oni w życiu rodziny. Dlatego ciała zmarłych grzebano w obrębie własnych osiedli i domostw. W odległych miejscowościach pogrzeby organizowali sami tubylcy, bez udziału kapłana. W Dzień Zaduszny w ramach podtrzymania prastarej tradycji mieszkańcy gór spożywali w sąsiedztwie grobów posiłki, które były ulubionymi daniami zmarłych. W tej „ceremonii” uczestniczyli również misjonarze. Misjonarze spotykali się z nieprzewidywalnymi sytuacjami także podczas udzielania sakramentu chrztu. Niektórzy z rodziców pragnęli bowiem nadać swoim dzieciom imiona: Lenin, Stalin ${ }^{34}$ czy nawet Hitler ${ }^{35}$.

Zupełnie inaczej przebiegała praca w stolicy Peru - Limie. Prowadzenie parafii okazało się o wiele trudniejszym zadaniem niż w jakiejkolwiek parafii w Polsce. Było to zadanie przede wszystkim niebezpieczne, a to $\mathrm{z}$ racji działalności terrorystycznego ugrupowania Sendero Luminoso. Częste zamachy, strach i śmierć niepodzielnie panowały nad 8-milionową metropolią. Odgłos wybuchów i strzelaniny słychać było również w pobliżu kościoła i budynków parafialnych. Trudno

${ }_{32}$ Zob. Акрк, Korespondencja ojców Zbigniewa, Jarosława i Michała do prowincjała z 3.10.1989.

33 Zob. Relacja bpa Luisa Bambaréna, Pariacoto, 2.02.199o.

34 Było to swoiste „pokłosie” kursów w zsRR, w których uczestniczyli niektórzy Peruwiańczycy.

${ }_{35}$ Zob. Relacja o. Zbigniewa Strzałkowskiego, Pariacoto, 2.02.199o. 
było w takiej sytuacji budować czy rozbudowywać kościelne obiekty, czy choćby prowadzić w miarę „normalne” duszpasterstwo ${ }^{36}$.

Przełomowym wydarzeniem w dziejach franciszkańskiej misji w Peru był atak terrorystyczny na misjonarzy w Pariacoto 9 sierpnia 1991 roku. Bojownicy Świetlistego Szlaku zamordowali wówczas dwóch franciszkanów: o. Zbigniewa Strzałkowskiego i o. Michała Tomaszka. Ostatnie chwile ich życia zostały odtworzone na podstawie zeznań bezpośrednich świadków (il. 7-9) ${ }^{37}$. Po tragicznych wydarzeniach w odległym Pariacoto aktywność misji franciszkańskiej znacznie osłabła. Zastraszenie ludności oraz obawy zakonu przed niepewnie rysującą się przyszłością w Peru w związku z coraz śmielej poczynającymi sobie senderystami nakazywały dużą ostrożność w podejmowaniu kolejnych inicjatyw misyjnych. Niemniej generał zakonu o. Lanfranco Serrini po konsultacji z papieżem Janem Pawłem II i zarządem prowincji w Krakowie uznał, że misja peruwiańska nie powinna być przerwana. Misjonarzom zalecono jednak, aby na pewien czas opuścili Pariacoto. Przez dwa lata zakonnicy posługiwali w tej placówce, okazyjnie dojeżdżając z Limy. W tym czasie pracy w Pariacoto podjął się kapłan z diecezji Chimbote Luis de Carpio ${ }^{38}$. Franciszkanie wrócili do Pariacoto po trzech latach. Jako pierwszy przybył tu o. Stanisław Olbrycht, doświadczony misjonarz z Boliwii, i stał się kontynuatorem dzieła męczenników ${ }^{39}$.

Biorąc pod uwagę sytuację, w jakiej znaleźli się misjonarze po ataku w Pariacoto, praca $\mathrm{w}$ Limie także nie była pozbawiona ryzyka. Zakonnicy pracowali w napięciu i niepewności, świadomi grożącego im w każdej chwili zagrożenia. W planach rozwoju misji przewidziano wysłanie kolejnych trzech misjonarzy do Peru, ale po ataku na Pariacoto decyzję odłożono w czasie. Zakonnicy, którzy zgłosili się do pracy w misji peruwiańskiej, zostali wysłani do Kolumbii, gdzie mieli nauczyć się języka hiszpańskiego, poznać iberoamerykańską kulturę i zwyczaje oraz zaaklimatyzować się do tamtejszych warunków. Nie zrezygnowali jednak z udania się do Peru ${ }^{40}$.

Inne trudności napotkali misjonarze w Chimbote - mieście położonym nad Pacyfikiem. Mieszkańcy trudnili się rybołówstwem i pracowali w hutach żelaza. W przejętej w 1995 roku parafii prowadzonej wcześniej przez misjonarzy z USA

${ }^{36}$ Zob. APL, Crónica Lima, s. 137.

37 Zeznania s. Lucili Reinoso i s. Berty Hernández Guerra zob. Z. Gogola, Działalność misyjna..., dz. cyt. s. 442-458; Z. Gogola, W peruwiańskie Andy..., dz. cyt., s. 177-193.

${ }_{38}$ Zob. Misja w Pariacoto będzie kontynuowana, „Czas Krakowski” 390 (1991) nr 185, s. 12.

${ }^{39}$ Zob. Peru, „Wiadomości z Prowincji” (1994) nr 193, z. 2, s. 25.

40 Zob. Акрк, Korespondencja o. Marka Wilka do prowincjała, Medellin 19.02.1992. 
spodziewano się, że również Polacy hojnie wesprą finansowo parafian ${ }^{41}$. Polacy nie mogli jednak kontynuować praktyki swoich amerykańskich poprzedników w zakresie wydatnej pomocy materialnej. Zadania duszpasterskie, jakie stanęły przed nimi, zdawały się przekraczać ich możliwości. Dwóch misjonarzy nie mogło sprostać wszystkim duszpasterskim wyzwaniom tak ogromnej wspólnoty parafialnej, nie mówiąc już o jakiejkolwiek pomocy materialnej, która wobec przybierającego na sile bezrobocia stawała się wymogiem chwili. Zarówno w części miejskiej, jak i wiejskiej parafii rosła przepaść ekonomiczna pomiędzy nieliczną grupą bogatych a rzeszą ubogich. Dodatkowo w części miejskiej parafii mieszkańcom dotkliwie uprzykrzały życie grasujące bandy. Niekiedy stawali się oni ofiarami krwawych porachunków pomiędzy gangami. Również misjonarzom nie dane było żyć w spokoju. Często odbierali telefony z pogróżkami, grożono im nawet śmiercią ${ }^{42}$. Zastraszanie i różne formy zniechęcania misjonarzy do pracy były inspirowane przez działaczy Sendero Luminoso, z których wielu było parafianami franciszkanów ${ }^{43}$. Między innymi w 1995 roku takie pogróżki otrzymał o. Marek Wilk. Żył w ciągłym stresie i w świadomości grożącego mu śmiertelnego niebezpieczeństwa. Żądano od misjonarza określonej sumy pieniędzy za „darowanie” życia. Pogróżki były na tyle poważne, że musiał opuścić Chimbote ${ }^{44}$. Na jego miejsce przybył o. Szymon Chapiński, doświadczony misjonarz z Limy, który sprawdził się już w podobnych sytuacjach. Dołączył do niego o. Michael Stockinger z Niemiec, którego tak zafascynowało męczeństwo franciszkanów z Pariacoto, że postanowił zostać misjonarzem w Chimbote ${ }^{45}$.

Oprócz wspomnianych trudności należy dodać negatywne oddziaływanie sekt i grup religijnych, które w dużej mierze jest wynikiem słabnącej siły integracyjnej Kościołów chrześcijańskich. Destruktywne działania różnego rodzaju grup kultowych są w istocie konfesyjną patologią i znacznie utrudniają pracę misyjną ${ }^{46}$. Innym jeszcze problemem utrudniającym pracę misjonarską jest występujące coraz szerzej niedożywienie, a nawet nasilający się głód i epidemie,

${ }^{41}$ Już w październiku 1990 roku postanowiono przyjąć ofertę pracy duszpasterskiej w Chimbote. Ze względu na śmierć misjonarzy w Pariacoto decyzję odłożono na kilka lat. Zob. AKPK, Protokół z posiedzenia Rady Prowincjalnej z 1.10.199o; Korespondencja prowincjała do bpa w Chimbote $z$ 21.10.1994.

${ }^{42}$ Zob. Relacja o. Marka Wilka, Chimbote, 6.02.1995.

43 Zob. Relacja o. Stanisława Niedzieli, Chimbote, 8.02.1995.

44 Zob. АКРК, Korespondencja o. Marka Wilka do prowincjała z 10.09.1995.

${ }_{45}$ Zob. Relacja o. Michaela Stockingera, Chimbote, 2.08.2001.

${ }^{46}$ Zob. Relacja Hilario Risco Orbegozo, Alcalde Pariacoto, Pariacoto, 8.08.2001. 
które są przyczyną wielu chorób i przedwczesnych zgonów, zwłaszcza wśród dzieci. Epidemie zwykle swoim zasięgiem obejmują nie tyle znaczne obszary, ile sporą populację ludzi najbiedniejszych. W roku 1991 na cholerę zapadło około 100 tysięcy osób ${ }^{47}$.

$\mathrm{Z}$ dnia na dzień powstają nowe dzielnice nędzy. Tworzą je przybywający do miasta mieszkańcy gór w nadziei polepszenia swego bytu. Wokół Limy rozciąga się około 350 dzielnic nędzy zamieszkałych głównie przez Indian Keczua ${ }^{48}$. Peru jest jednym $\mathrm{z}$ krajów, gdzie dysproporcja między bogatymi a biednymi jest bardzo głęboka. W latach 9o. xx wieku liczba najuboższych sięgała $2 / 3$ ogółu populacji ${ }^{49}$. W Peru odnotowano jeden $\mathrm{z}$ najgorszych wskaźników odżywiania, biorąc pod uwagę całość kontynentu Ameryki Południowej. Problemu tego zdają się nie zauważać sprawujący władzę w państwie ${ }^{50}$.

Trudności duszpasterskie wynikają często z braków ekonomicznych i obniżenia świadomości moralnej: to ważki problem, z którym muszą się zmierzyć misjonarze. W społeczeństwie peruwiańskim, szczególnie pośród Indian Keczua, najważniejszą rolę w domu odgrywają kobiety: matka i babka. One stanowią centrum, wokół którego toczy się życie rodzinne. Mężczyźni zakładają rodziny, często nie biorąc ślubu, pozwala im to na odejście z domu bez ponoszenia żadnych konsekwencji. Zdarza się, że wracają, ale sprowadzają ze sobą drugą kobietę. Wiele dzieci pracuje od najmłodszych lat, wiele wychowuje ulica ${ }^{51}$. Nikt się o nie nie troszczy. Przybywa też osób, które nie są ochrzczone.

Kolejną przeciwnością misjonarza w Andach jest klimat i jego znaczne zróżnicowanie związane z dużymi różnicami wysokości. Rozrzedzone powietrze wysokogórskie powoduje zaburzenia w funkcjonowaniu organizmu. Dotyczy to jedynie cudzoziemców. Organizm tubylców jest bowiem naturalnie dostosowany do panujących tam warunków. Dzięki większej o 25 proc. pojemności płuc i większej objętości serca czują się dobrze w wysokich górach ${ }^{52}$.

47 Zob. APL, Crónica Lima, s. 86.

${ }^{48}$ Zob. H. Jabłoński, Świat nie kręci się wokół Andów, Warszawa 1986, s. 105-106.

49 Zob. J. B. Dammert, Pobreza, ética y eficacia, „Paginas” (1994) nr 130, s. 81.

5o Zob. M. Nowak, Biedni w Ameryce Lacińskiej: przedsiębiorcy, nie proletariusze, [w:] Pokrętne ścieżki. Konfrontacje, New York 1989, s. 167-170.

${ }^{51}$ Czteroletni chłopcy czyszczą przechodniom buty w parkach, na ulicach, dworcach (z obserwacji autora).

${ }^{52}$ Zob. R. Warszewski, Inicjacja, Kraków 1987, s. 62-68. 


\section{Wpływ misji franciszkańskiej na sytuację Kościoła w Peru}

Po upływie 25 lat od rozpoczęcia misji w Peru nasuwa się pytanie: co współczesna misja franciszkańska przyniosła Kościołowi w Peru? Co przyniosła śmierć misjonarzy mieszkańcom Pariacoto? Odpowiedź na tak postawione pytania nie jest ani oczywista, ani prosta. Usiłuję jednak ukazać pewne aspekty misyjnej obecności polskich franciszkanów w historii tamtejszego Kościoła. Małe, ukryte w Andach Pariacoto stało się miejscem pielgrzymek do grobów męczenników. Osada zyskała nowych i ważnych patronów. Jedną z ulic mieszkańcy nazwali imieniem ojców Zbigniewa i Michała. Istnieje przekonanie, że śmierć misjonarzy była ofiarą, która przyniosła $\mathrm{w}$ dużej mierze uwolnienie $\mathrm{z}$ lęku przed terrorystami. Ludzie zaczęli otwarcie rozmawiać o terroryzmie i przemocy, o zabójstwie i męczeńskiej śmierci franciszkanów. Niektórzy mieszkańcy przyznali się, że byli naocznymi świadkami egzekucji ${ }^{33}$. Śmierć ta wniosła do wielu serc pokój i odwagę. Aktywność ugrupowania Sendero Luminoso zmniejszyła się, a jej przywódca Abimael Guzmán odsiaduje dożywocie w peruwiańskim więzieniu. Wszystko to stwarza nową perspektywę dla chrześcijaństwa w Peru. Wydaje się, że niektórzy głosiciele „teologii wyzwolenia” zrozumieli, że nie walka, ale pojednanie ze wszystkimi ludźmi, także z krzywdzicielami, wiedzie do prawdziwego pokoju i dobrobytu ${ }^{54}$.

Pamięć o męczeńskiej śmierci przyniosła też zmianę sposobu postrzegania swego środowiska. Mieszkańcy Peru zaczęli spoglądać śmielej i uważniej na to, czego dotąd się bali. Uświadomili sobie, że zwycięstwo zła jest tylko pozorne. Zakon franciszkański także zmienił swoją optykę patrzenia na przyszłość misji. Śmierć zaowocowała nowymi powołaniami do zakonu. Zmian, jakie nastąpiły po śmierci męczenników, jest wiele, niektóre - te w sercach ludzkich - są nieuchwytne i nie do opisania przez historyka. Biskup Luis Bambarén stwierdził: „Krew męczenników pokrzepia nas, wzmacnia, podtrzymuje wiarę i pokój w sercach w chrześcijańskich wspólnotach w Pariacoto i okolicy"55. Pewna grupa ludzi w Pariacoto przyznała, że ponosi winę za to, co wydarzyło się przed laty. Zanim męczennicy zostali wyniesieni na ołtarze, wielu ludzi już modliło się przez ich wstawiennictwo. Chorzy przykładali do obolałych części ciała ich wizerunki, nie manifestując wszakże tej praktyki na zewnątrz (il. 10, 11) ${ }^{56}$.

53 Zob. Relacja Abundio Caballero Cabana, Pariacoto, 30.07.2001.

${ }_{54}$ Zob. Relacja bpa nominata Salvadore Piñeiro z Limy, 9.09.2001.

${ }_{55}$ Relacja bpa Luisa Bambaréna, Pariacoto, 9.08.2001.

${ }_{56}$ Zob. Relacja o. Stanisława Olbrychta, Pariacoto, 14.07.2009. 
W związku z procesem beatyfikacyjnym Kościół peruwiański stał się bardziej świadomy swego posłannictwa i siły w posłudze ubogim i uciśnionym. Są też przesłanki, by sądzić, że Kościół w Peru zaczął być bardziej solidarny z campesinos i znajdującymi się w bardzo trudnej sytuacji socjalnej robotnikami, narażając się tym samym władzy państwowej. Nie można jednak zapominać, że ewangelizacja i chrzest nie mogą być zastąpione bądź choćby tylko zdominowane przez działania społeczno-gospodarcze ${ }^{57}$. Zamordowani misjonarze zostali uznani przez peruwiański episkopat za męczenników. Ułatwiło to w dużym stopniu rozpoczęcie, prowadzenie i ukończenie procesu beatyfikacyjnego $0^{58}$. Biskup Luis Bambarén w rozmowie z uwięzionym przywódcą komunistycznej organizacji Świetlistego Szlaku Abimaelem Guzmánem usłyszał słowa: „Kazałem zabić tych polskich misjonarzy z nienawiści do religii. Myślałem wtedy, że tak trzeba, bo religia to opium dla ludu" ${ }^{59} .5$ grudnia 2015 roku odbyła się w mieście Chimbote w Peru beatyfikacja zamordowanych przez Sendero Luminoso misjonarzy: o. Zbigniewa Strzałkowskiego, o. Michała Tomaszka i kapłana włoskiego ks. Aleksandra Dordiego. Prefekt Kongregacji Spraw Kanonizacyjnych kard. Angelo Amato w kazaniu podczas mszy świętej beatyfikacyjnej uświadomił słuchającym, że męczennicy z Pariacoto uczą przesłania wiary, trwając w misji mimo zagrożenia życia, następnie uczą miłości, którą oni przeżywali wśród potrzebujących, i po trzecie uczą wierności powołaniu chrześcijańskiemu i misyjnemu. Język miłości, pokoju i pojednania, jakim się posługiwali męczennicy, był prawdziwym „świetlistym szlakiem” ${ }^{60}$.

\section{Zakończenie}

Podsumowując skomplikowane realia misji peruwiańskiej, trzeba podkreślić, że największą trudnością dla polskich franciszkanów była sytuacja polityczna,

57 Zob. J. Górski, Misja Kościoła według Jana Pawła II, „Światło Narodów” (1995) nr 14, s. 11.

${ }^{8}$ Konferencja Episkopatu Peru w dniu 24 stycznia 1995 roku podjęła decyzję, aby uznać zamordowanych franciszkanów za męczenników i rozpocząć proces beatyfikacyjny ojców Strzałkowskiego i Tomaszka jako męczenników. W dniu 5 czerwca 1995 roku Kongregacja Spraw Kanonizacyjnych wyraziła zgodę na wszczęcie takiego procesu na rok przed okresem przewidzianym przez prawo kanoniczne (aktualnie pięć lat po śmierci sługi Bożego). Zob. Archiwum Diecezji w Chimbote, Pismo urzędowe Kongregacji do Spraw Świętych do bpa Luisa Bambaréna, 5.06.1995, Prot. N. 2038-2/95.

59 Relacja bpa Luisa Bambaréna, Lima, 7.12.2015.

60 Z. Gogola, Z kazania kardynała Angelo Amato, Chimbote, 5.12.2015. 
w jakiej znalazł się naród peruwiański i Kościół. Abimael Guzmán, twórca Komunistycznej Partii Peru, a w istocie terrorystycznego ugrupowania Sendero Luminoso, postawił sobie za cel przejęcie władzy w kraju. Metoda była bardzo prosta i wypróbowana w wielu krajach komunistycznych. Było nią zabijanie „wrogów ludu”, choćby nawet z tego ludu się wywodzili. Wrogiem był również Kościół, jego hierarchia, szeregowi kapłani i misjonarze. Ci ostatni poprzez swoją pracę charytatywną „usypiali” - zdaniem senderystów - rewolucję, więc byli szczególnie niebezpieczni. Wbrew zamierzeniom bojowników ze Świetlistego Szlaku zbrodnia na dwóch misjonarzach nie była ich zwycięstwem ani klęską Kościoła. Przeciwnie, dzięki męczeństwu Kościół peruwiański zmężniał, umocniła się wiara pośród obywateli kraju, a misje otrzymały impuls do jeszcze bardziej wzmożonego apostolstwa. Obecność franciszkanów została oceniona przez tamtejszy Kościół pozytywnie. Sami franciszkanie stali się trwałym elementem najnowszych dziejów chrystianizacji Peru. Model pracy misyjnej Braci Mniejszych Konwentualnych na przełomie wieków xx i xxı zdał egzamin i okazał się skuteczny. Uzyskane doświadczenia będą zapewne pomocne w dalszej działalności ewangelizacyjnej w strukturach peruwiańskiego Kościoła. Największym, choć niewymiernym sukcesem pozostała codzienna praca duszpasterska, pomoc charytatywna i sama obecność wśród tysięcy Peruwiańczyków, w kraju, gdzie liczba kapłanów jest zbyt mała w stosunku do potrzeb.

Gdy w 1987 roku franciszkanie przygotowywali się do podjęcia misji w Peru, nikt nie przypuszczał, że mała andyjska wioska Pariacoto stanie się sanktuarium męczeństwa polskich misjonarzy, błogosławionych: o. Zbigniewa Strzałkowskiego i o. Michała Tomaszka. 


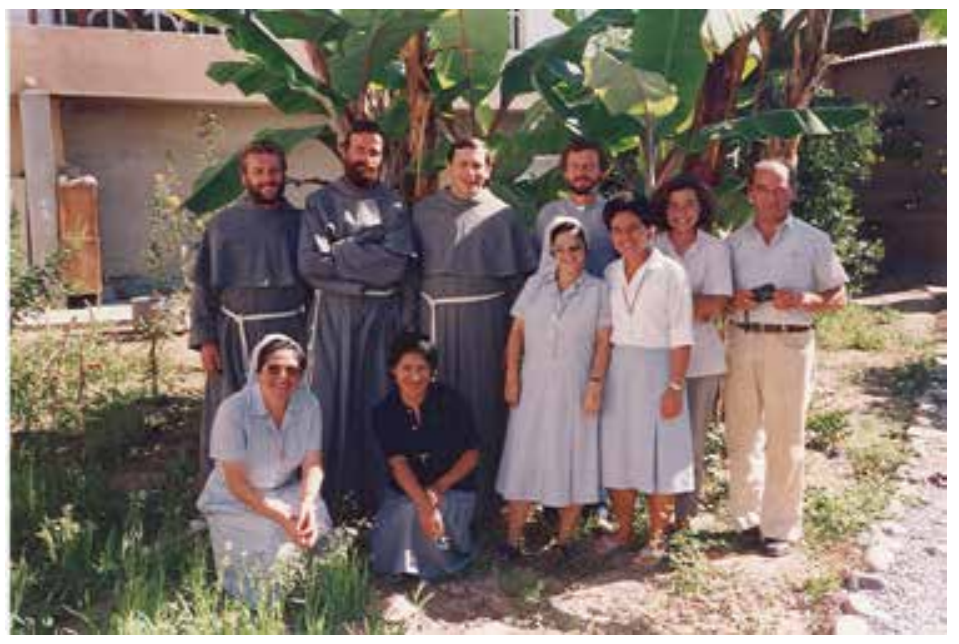

1. Pariacoto (1990); od lewej: o. Zbigniew Strzałkowski, o. Michał Tomaszek, o. Zdzisław Gogola - prowincjał, o. Jarosław Wysoczański, o. Szymon Chapiński, siostry misjonarki. Fot. archiwum autora

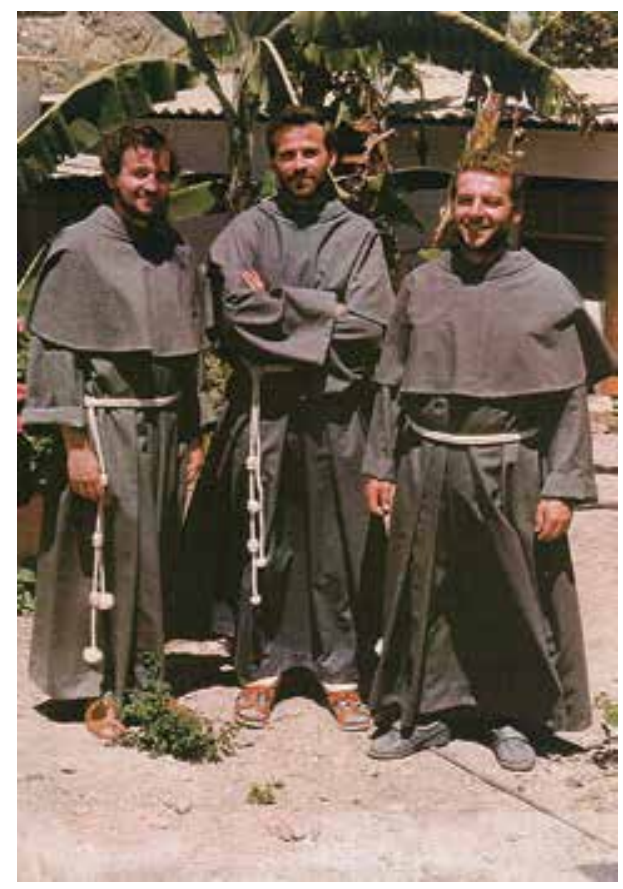

2. Pariacoto (1990);

o. Jarosław Wysoczański,

o. Michał Tomaszek,

o. Zbigniew Strzałkowski.

Fot. archiwum autora 


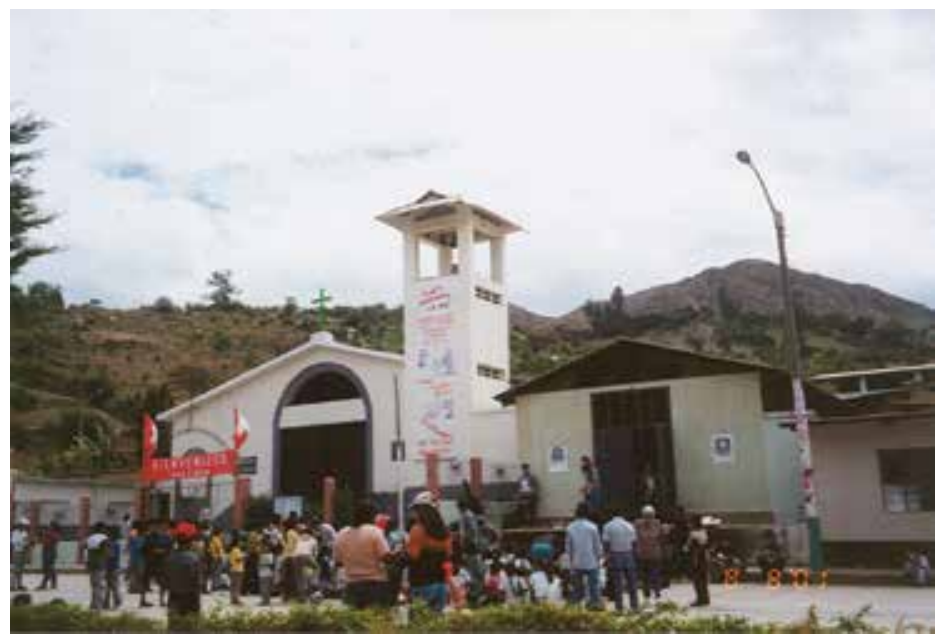

3. Pariacoto, kościół.

Fot. archiwum autora

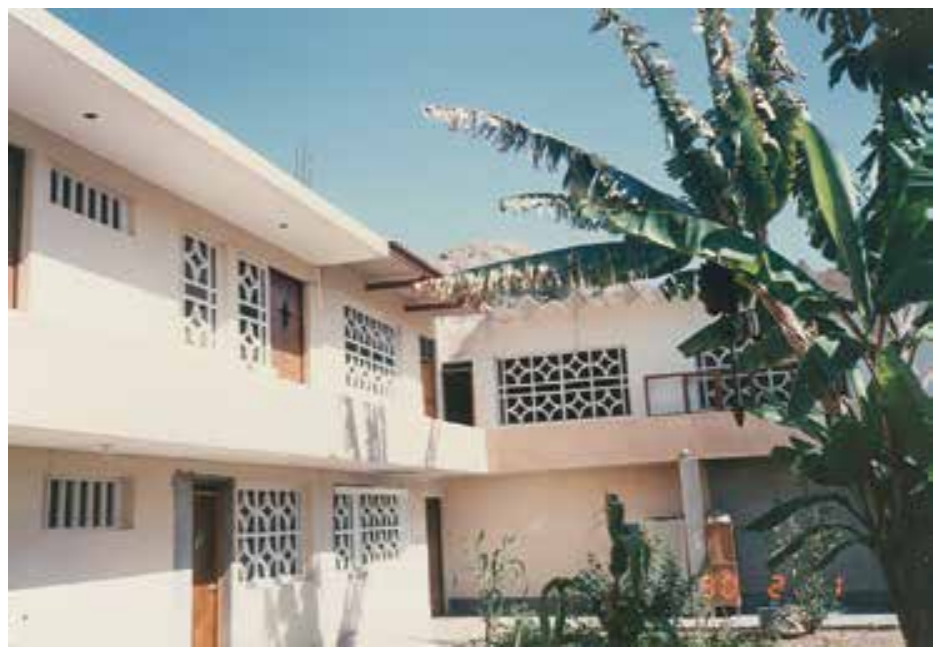

4. Pariacoto (1990), klasztor od strony wirydarza.

Fot. archiwum autora 


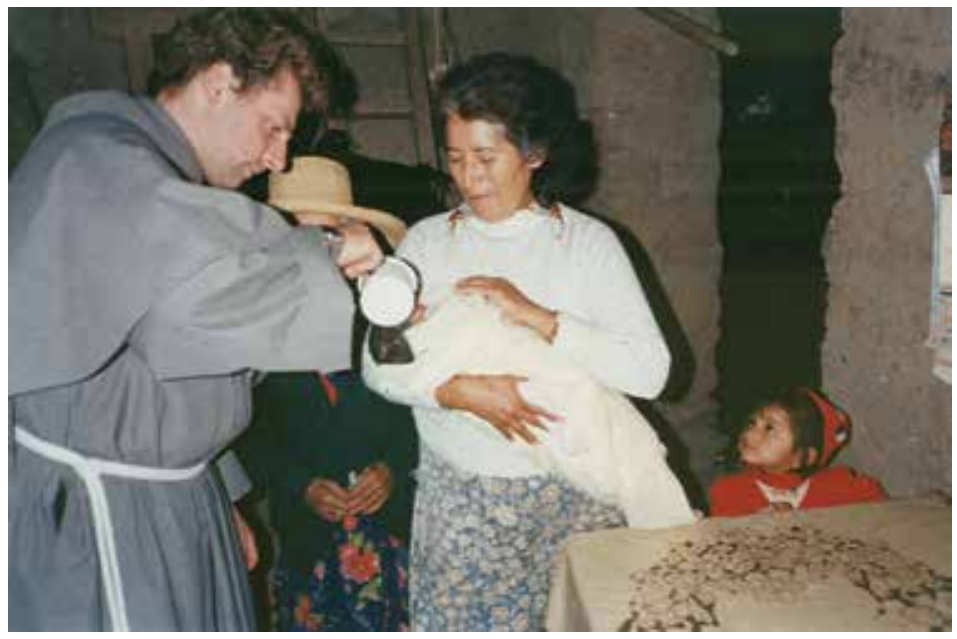

5. O. Zbigniew Strzałkowski udziela chrztu świętego. Fot. archiwum autora

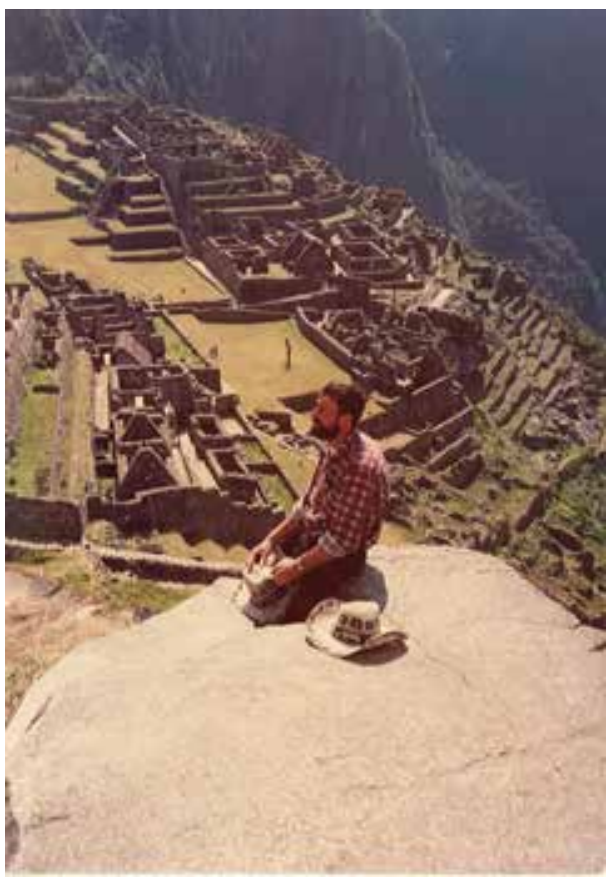

6. O. Michał Tomaszek na tle ruin Machu-Picchu. Fot. archiwum autora 


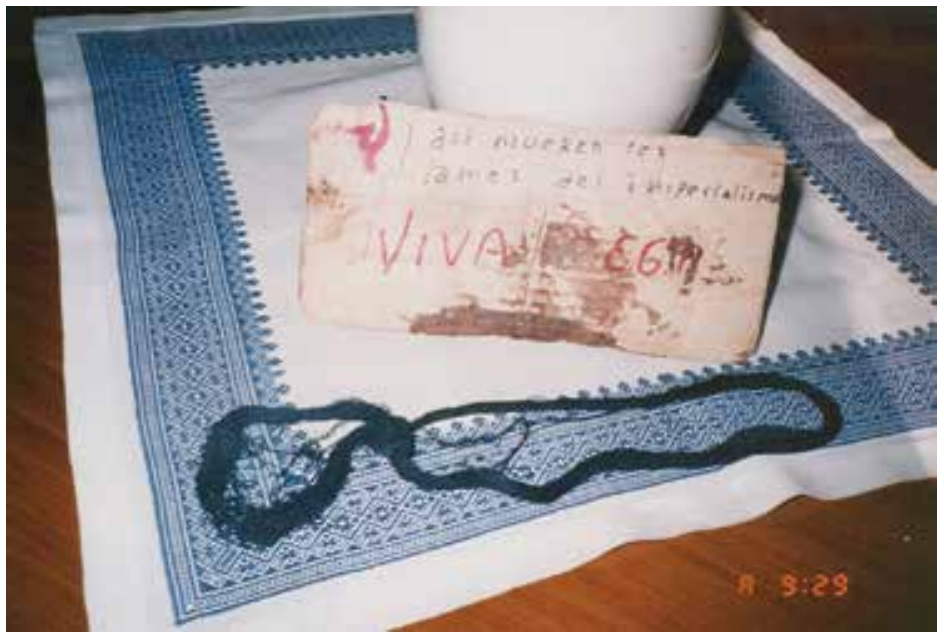

7. Tabliczka z tektury pozostawiona przez terrorystów na plecach o. Zbigniewa Strzałkowskiego „Tak giną psy imperializmu”. Fot. archiwum autora

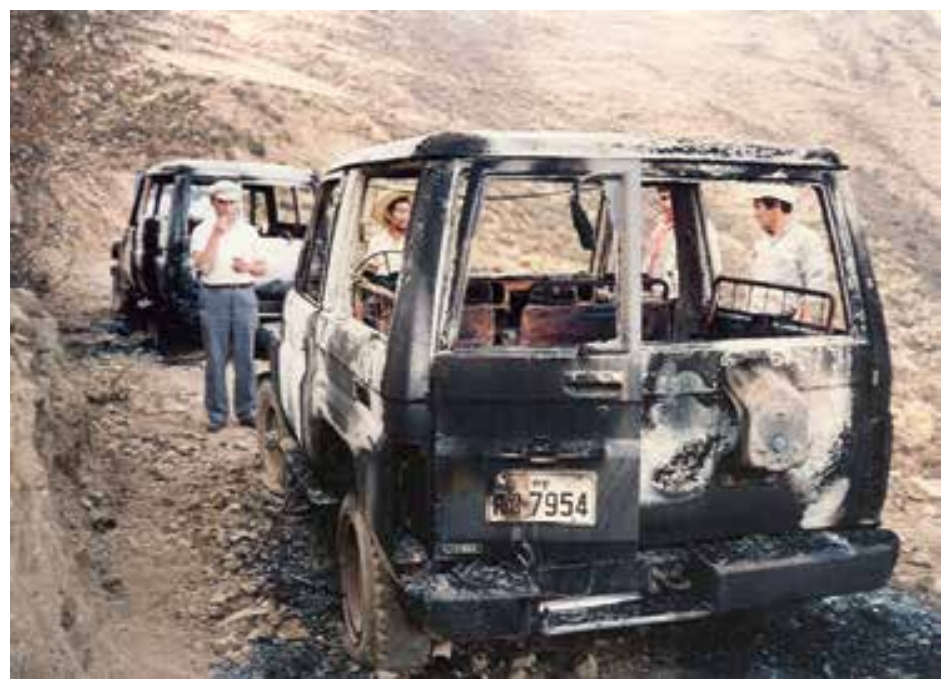

8. Spalone samochody, którymi wywieziono misjonarzy. Fot. archiwum autora 


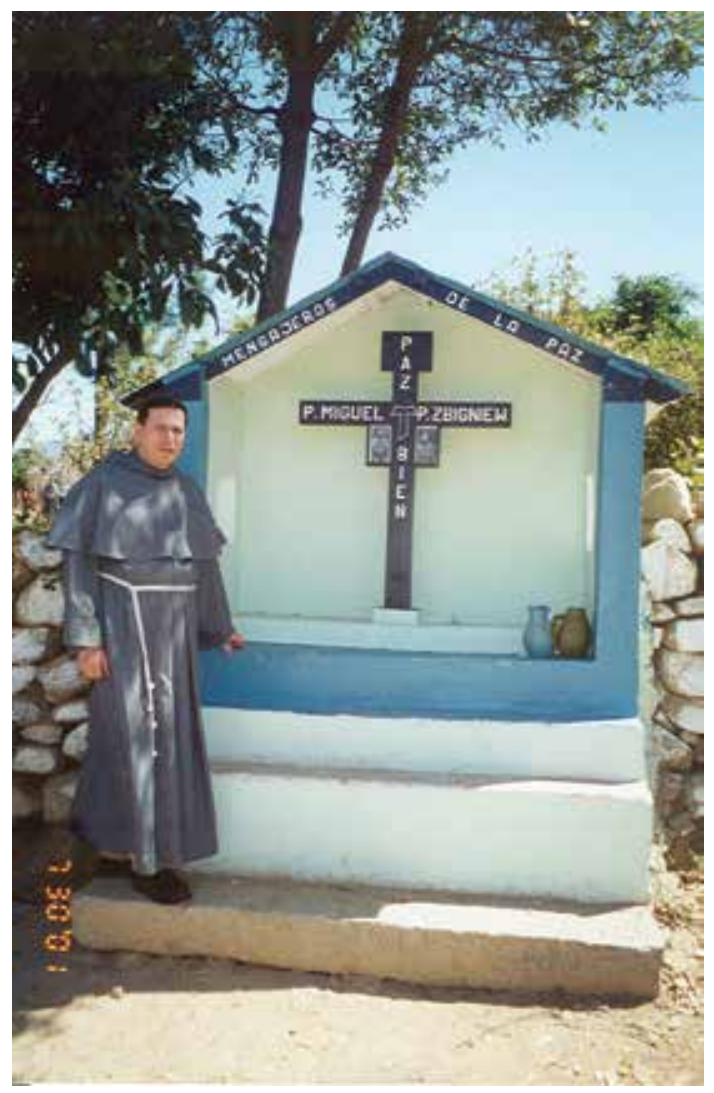

9. Kapliczka w miejscu męczeństwa

o. Zbigniewa i o. Michała, Pariacoto (2001), o. Zdzisław Gogola OFM Conv.

Fot. archiwum autora 


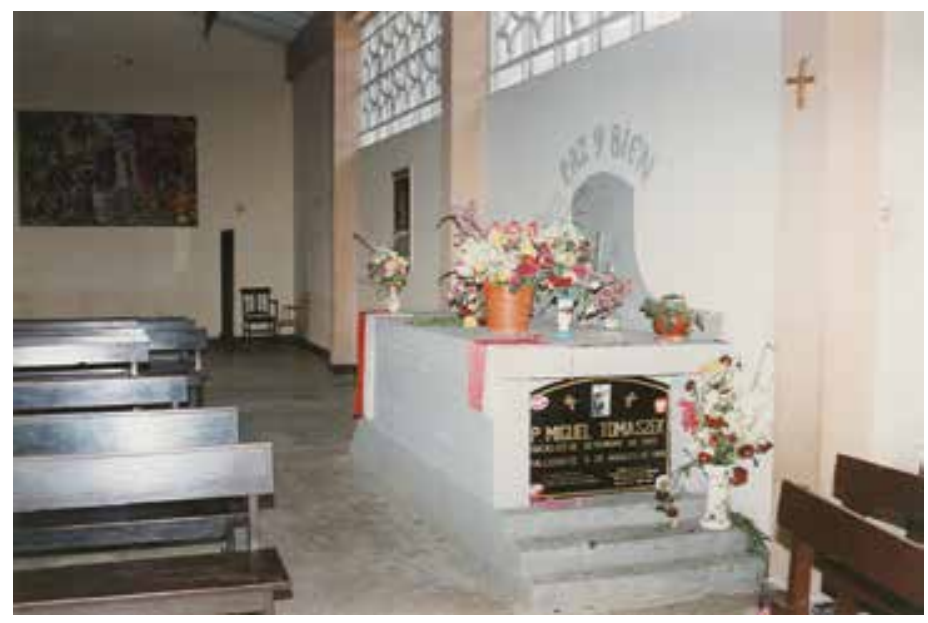

10. Grób o. Michała Tomaszka.

Fot. archiwum autora

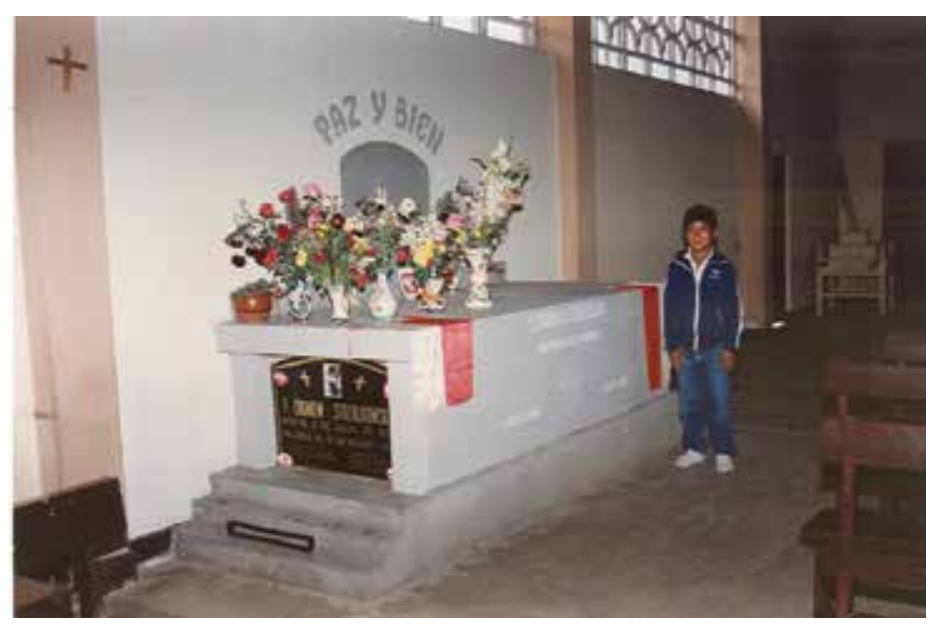

11. Grób o. Zbigniewa Strzałkowskiego.

Fot. archiwum autora 